\title{
Anatomía del Peritoneo Digestivo del Ñandú (Rhea americana)
}

\author{
Digestive Peritoneum Anatomy of the Rhea (Rhea americana)
}

Richard Möller \& Diana Teliz

MÖLLER R. \& TELIZ, D. Anatomía del peritoneo digestivo del Ñandú (Rhea americana). Int. J. Morphol., 27(4):981-984, 2009.

RESUMEN: El ñandú (Rhea americana) es un ave corredora autóctona de Sudamérica la cual hace ya algunos años ha despertado cierto interés productivo. Sin embargo, la morfología detallada a nivel de las aves domésticas aún se desconoce en muchos aspectos; entre ellos el peritoneo. El objetivo de este trabajo es describir el peritoneo parietal, visceral y de conexión del ñandú acorde con los principios de la Nómina Anatómica Aviar. Se utilizaron 7 animales adultos; 5 machos y 2 hembras de entre 8 y $25 \mathrm{~kg}$. de peso procedentes de un criadero comercial. Fueron eutanasiados por sobredosis de tiopental sódico. La cavidad peritoneal estaba dividida en una parte craneal (equivalente a 1/3) y una parte caudal al estómago (equivalente a 2/3 del total del abdomen). En la parte caudal se encontraba la totalidad del intestino y el páncreas, mientras que en la parte craneal se observó el hígado y la vesícula biliar. Un omento menor fijaba el estómago al hígado cranealmente hacia la derecha y un omento mayor pequeño con una bolsa omental cerrada lo fijaba caudalmente hacia la izquierda. La raíz del mesenterio fijaba al yeyuno, al íleon y a ambos ciegos entre sus hojas a través de amplios pliegues ileocecales. Desde la raíz del mesenterio un corto mesoduodeno sujetaba al duodeno descendente y ascendente hacia la derecha. El colon estaba sostenido por un amplio mesocolon desde distal a la desembocadura de los ciegos hasta su terminación en la cloaca. Se concluye que esta especie corredora presenta similitudes con las aves domésticas. Sin embargo, lo relativamente grueso y fuerte del peritoneo de conexión sumado a lo compartimentado de la cavidad peritoneal hacen suponer que se trata de una adaptación para la carrera al permitir una gran sujeción de las vísceras abdominales.

PALABRAS CLAVE: Aparato digestivo; Viscera; Morfología; Anatomía macroscópica; Ave corredora.

\section{INTRODUCCIÓN}

El ñandú (Rhea americana) es un ave corredora (ratite) autóctona del sur de Sudamérica la cual ha despertado hace algunos años cierto interés para la producción de carne, cueros, plumas y huevos. El conocimiento científico de su morfología, fisiología, patología, parasitología, reproducción, etc. influyen positivamente en dicha producción. Varios autores han escrito acerca de temas vinculados a la producción. Asimismo existen varios trabajos sobre patologías y tratamientos en el aparato digestivo del avestruz (Struthio camelus) (Gamble \& Honnas, 1993; Honnas et al., 1991, 1993; Huchzermeyer et al., 1993; Perelman, \& Kuttin, 1992; Sanford \& Rehmtulla, 1993; Sato et al., 1994; Shwaluk \& Finley, 1995; Terzich \& Vanhooser, 1993). Bezuidenhout et al. (1986) describieron la topografía abdominal del avestruz; Streicher et al. (1985) las pepsinas del proventrículo en el avestruz y Degen et al. (1994) la motilidad del estómago glandular también en el avestruz. Cooper \& Mahroze (2004) dan una breve descripción de la anatomía del aparato digestivo del avestruz focalizando su estudio sobre el apara- to digestivo en la etapa de crecimiento. Sin embargo, la morfología detallada del ñandú a nivel de las aves domésticas (McLelland, 1990; Yasuda, 2003) aún se desconoce en muchos aspectos. Detalles de su aparato digestivo, respiratorio, esqueleto, etc. no se han encontrado en la bibliografía consultada y la membrana serosa de la cavidad abdominal, el peritoneo, no se ha descrito hasta el momento. Siendo esta una especie de gran proyección en producción animal, consideramos importante realizar este aporte al conocimiento científico. El objetivo de este trabajo es describir el peritoneo parietal, visceral y de conexión del ñandú acorde con los principios de la Nómina Anatómica Aviar (Baumel, 1993).

\section{MATERIAL Y MÉTODO}

Se utilizaron 7 animales adultos (Rhea americana) 5 machos y 2 hembras de entre 8 y $25 \mathrm{~kg}$. de peso procedentes 
de una granja comercial. Fueron anestesiados con una dosis de inducción de $0,5 \mathrm{ml}$. de acepromacina, $1,5 \mathrm{ml}$ de diazepan y $1,5 \mathrm{ml}$ de ketamina por vía intramuscular. Luego se inyectó tiopental al $10 \%$ por vía intravenosa hasta la eutanasia. Fueron fijados con formol (40\%) diluido en agua al $10 \%$ el cual fue inyectado por vía percutánea en músculos y cavidades y se mantuvieron inmersos en formol al $10 \%$.

Para el estudio se realizó la apertura de la cavidad abdominal mediante una incisión media ventral desde el proceso xifoides hasta la cloaca. Se observó y describió el peritoneo que recubre la pared abdominal, el peritoneo visceral y el peritoneo de conexión que sostiene las vísceras digestivas.

\section{RESULTADOS}

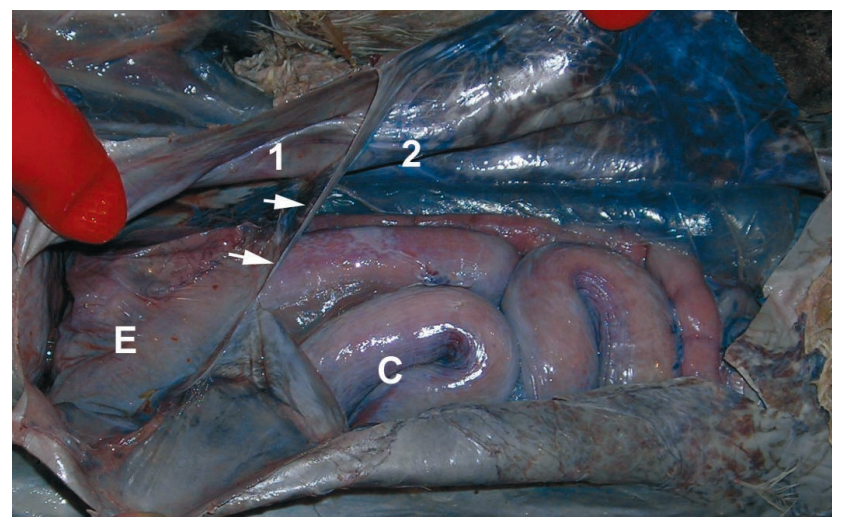

Fig. 1. Vista ventral in situ de la cavidad peritoneal. Flechas. peritoneo de conexión que sujeta el ventrículo a la parte ventral del abdomen. C; ciegos, E. Ventrículo (estómago muscular).

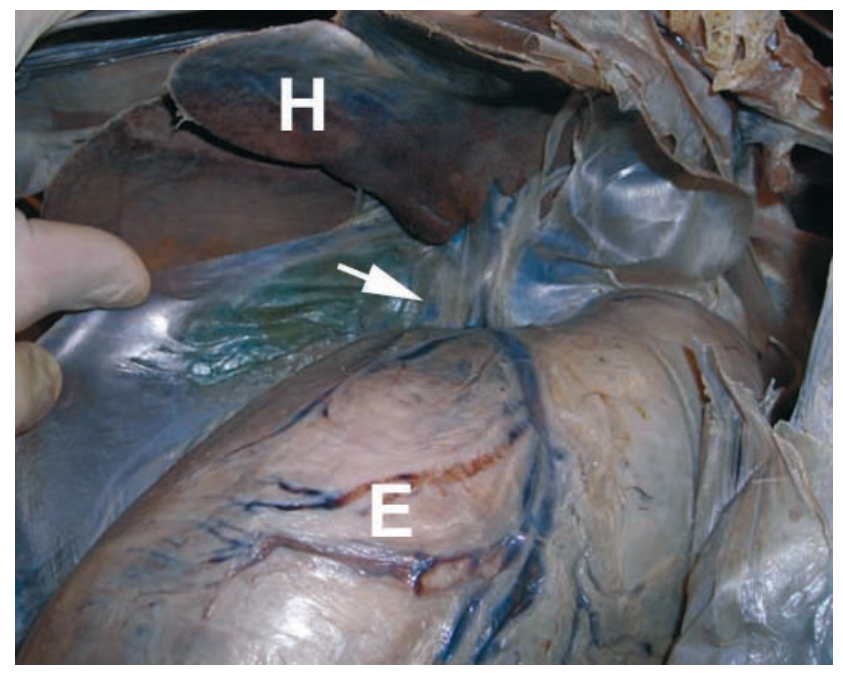

Fig. 2. Vista ventral. Flecha. omento menor. H. hígado; E: ventrículo.
El peritoneo parietal ventralmente mostraba una gran resistencia y se encontraba adherido a la fascia transversalis. Se observaba peritoneo de conexión que sujetaba la curvatura mayor del estómago muscular (ventrículo) hacia la pared abdominal ventral. (flechas, Fig. 1) y dorsalmente el ventriculus estaba firmemente adherido a la pared. De esta manera, el ventriculum dividía la cavidad peritoneal en una parte craneal (equivalente a 1/3) (1, Fig. 1) y una caudal

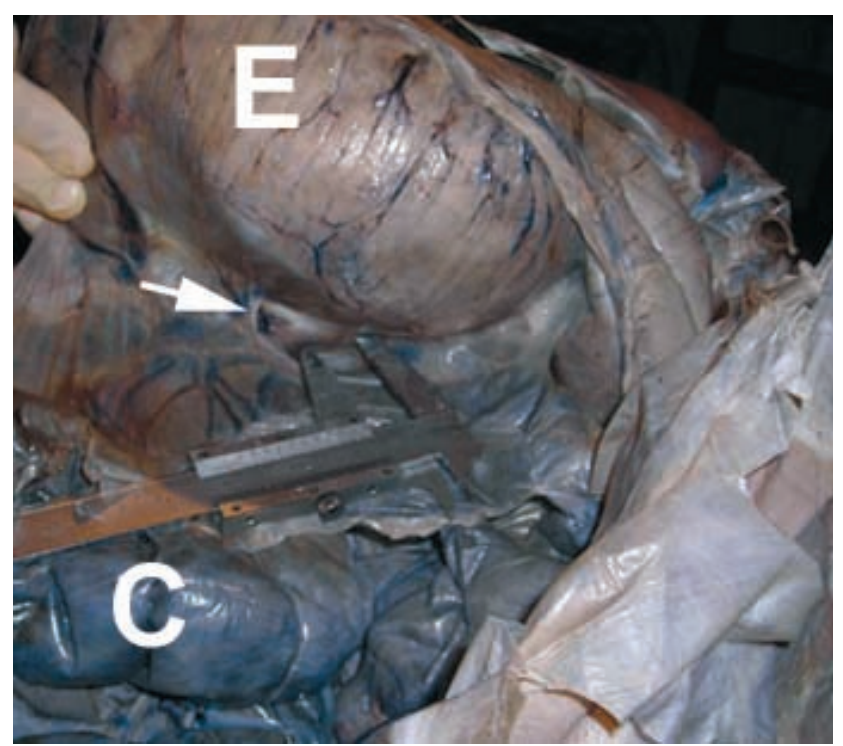

Fig. 3. Vista ventral izquierda. Flecha. foramen omental cerrado.

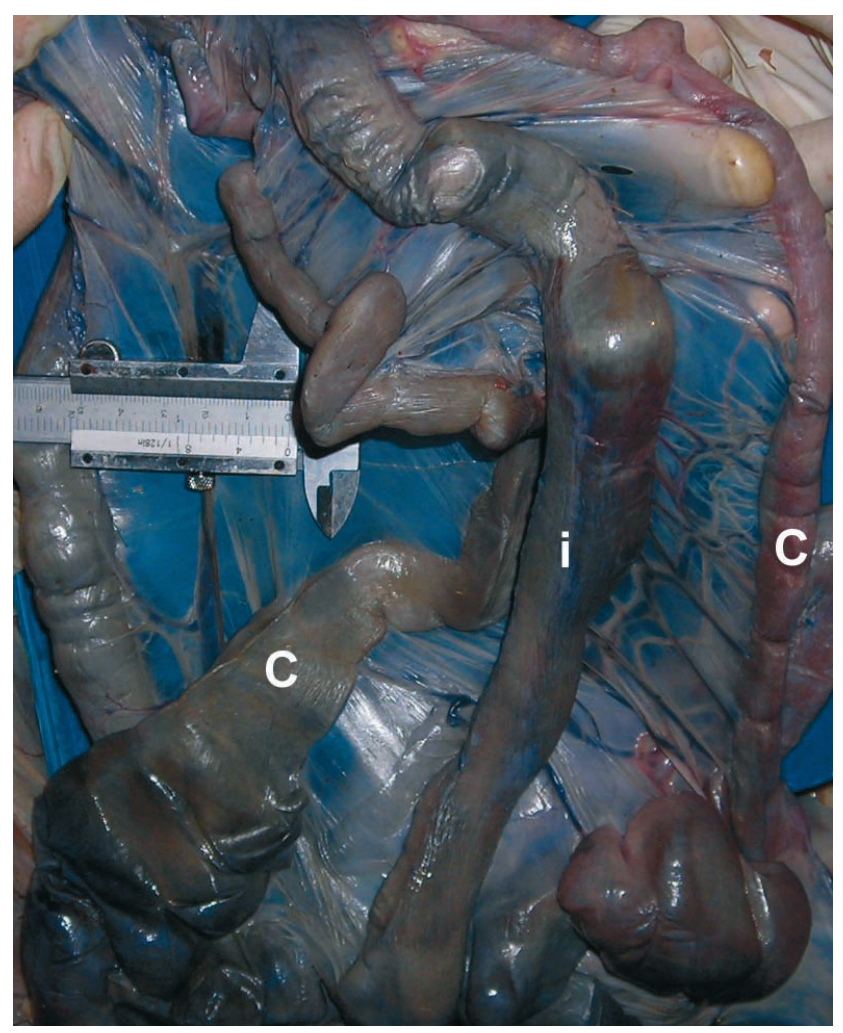

Fig. 4. Vista ventral del mesenterio. C. ciegos. I. íleon. 
(equivalente a $2 / 3$ del total del abdomen) (2, Fig. 1). En la parte craneal se observó el hígado y la vesícula biliar mientras que en la parte caudal se encontraba la totalidad del intestino y el páncreas. Un omento menor fijaba el ventriculum al hígado cranealmente hacia la derecha (flecha, Fig. 2) y un omento mayor pequeño con una bolsa omental cerrada (flecha, Fig. 3) lo fijaba caudalmente hacia la izquierda. No existía foramen omental. La raíz del mesenterio se ubicaba dorsalmente en la parte media del abdomen; fijaba al yeyuno, al íleon y a ambos ciegos entre sus hojas a través de amplios pliegues ileocecales (Fig. 4). Desde la raíz del mesenterio un corto mesoduodeno sujetaba al duodeno descendente y ascendente hacia la derecha del plano mediano (flecha, Fig. 5). El ciego izquierdo quedaba sujeto por un pliegue que lo unía con la hoja profunda (dorsal) de la bolsa omental (flecha, Fig. 6). El colon estaba sostenido por un amplio mesocolon en todo su trayecto.

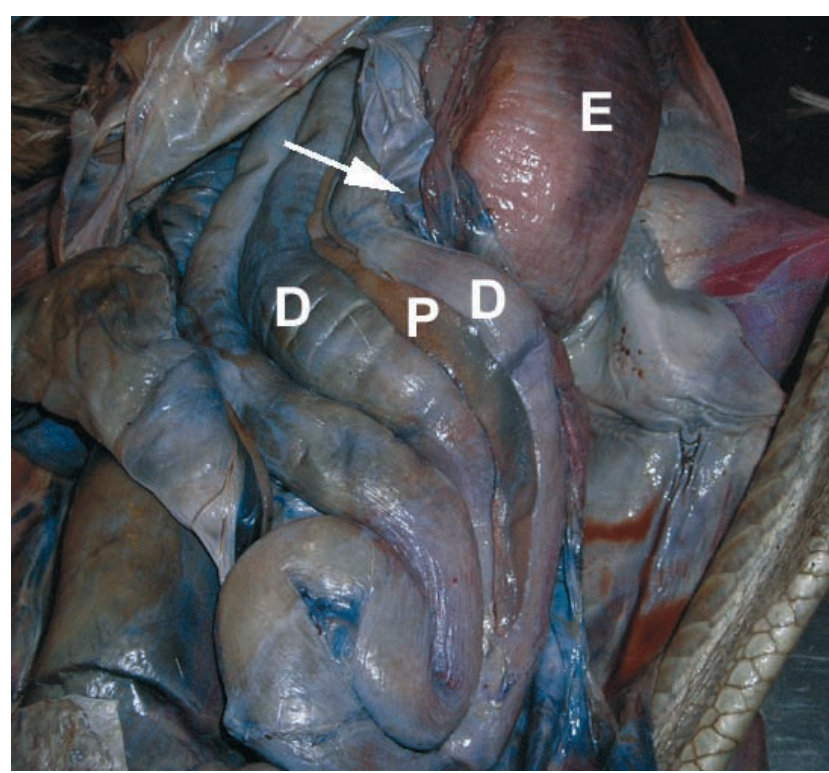

Fig. 5. Vista ventral del abdomen. Flecha. origen del mesoduodeno; E. ventriculus; D. duodeno; P. páncreas.

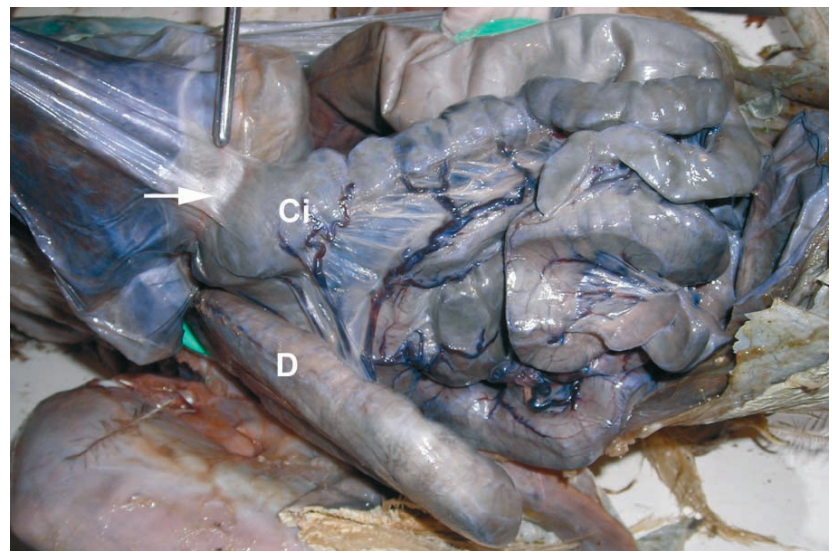

Fig. 6. Vista ventral. Flecha. unión del ciego izquierdo con la bolsa omental. Ci. ciego izquierdo; D. duodeno.

\section{DISCUSIÓN}

La descripción del peritoneo del ñandú no se ha encontrado en la bibliografía consultada. Nuestros estudios sobre el peritoneo del ñandú podrían aportar la base para la descripción en otras especies de aves. En general el peritoneo del ñandú mantiene las características de las aves en concordancia con la Nomina Anatomica Avium (Baumel, 1993).

La fijación del estómago muscular hacia ventral por un peritoneo de conexión fuerte y la adhesión de éste dorsalmente hacia la izquierda determina la compartimentación de la cavidad peritoneal esto, aunque similar a lo descrito para las aves en general, no es estrictamente igual de acuerdo a nuestros resultados. Según varios autores (Gamble \& Honnas; Honnas et al., 1991; Huchzermeyer et al.; Perelman \& Kuttin; Sanford \& Rehmtulla; Sato et al.; Shakespeare, 1995; Shwaluk \& Finley, 1995) la impacción del ventrículo y proventrículo en ratites es bastante frecuente y esto amerita un conocimiento más amplio de la anatomía y peritoneo de estas especies. En algún caso (Honnas et al., 1991, 1993) se ha procedido a realizar la cirugía para resolver esta dolencia. En los artículos que hacen referencia a las vísceras abdominales del avestruz (Bezuidenhout; Cooper \& Mahroze; Degen et al.) ninguno de ellos describe el peritoneo ni se dan detalles sobre la morfología del mismo.

Se concluye que esta especie corredora presenta similitudes importantes con las aves domésticas en cuanto a las partes del aparato digestivo y en el peritoneo. Sin embargo, lo relativamente grueso y fuerte del peritoneo de conexión sumado a lo compartimentado de la cavidad peritoneal hacen suponer que se trata de una adaptación para la carrera al permitir una gran sujeción de las vísceras abdominales.

\section{AGRADECIMIENTOS}

A la Señora Gloria Godoy por proveernos de los animales para las disecciones. Sin su aporte nuestro trabajo no hubiera sido posible.

MÖLLER R. \& TELIZ, D. Digestive peritoneum anatomy of the Rhea (Rhea americana). Int. J. Morphol., 27(4):981-984, 2009.

SUMMARY: The rhea (Rhea americana) is a native ratite from South America which has woken up since a few years ago a big productive interest. However the detailed morphology of the rhea at the level at the domestic birds is still unknown in many aspects, on of them is the peritoneum. The aim of this work is to describe the parietal, visceral and connection peritoneum of the rhea according to the anatomical avian nomenclature. Seven 
specimens of adult rhea were used, five males and two females about 8 and $25 \mathrm{~kg}$ of weight. All of them proceeding from a commercial farm. The animals were slaughtered before their study. The peritoneum that cover the abdominal wall and the visceral and connection peritoneum that support the abdominal viscera were observed and described. The peritoneal cavity were divided into two parts, one was craneal to the ventriculum (1/3 parts from the total of the abdomen) and the other was caudal (2/3). Into the cranial part we founded the liver and the gallbladder while into the caudal part we founded the intestine and the pancreas. The stomach was fixed to the liver cranially to the right by a minor omentus and caudally to the left was fixed by a small major omentus with a close omental bag. The root of the mesentery was fixing the yeyuno, ileum and both caecums between its sheets towards wide ileocecalis creases. From the mesentery root a short mesoduodenum was holding the descending and ascending duodenum towards the right. The colon was supported by a wide mesocolon. We concluded that this ratite has similarities with the domestic birds. Nevertheless, the thickness and strong connection peritoneum and the compartmentalization of the peritoneal cavity make us suppose that it is an adaption to the race since it is a big subjection to the abdominal viscera.

KEY WORDS: Digestive aparatus; Viscera; Morphology; Macroscopic anatomy; Ratites.

\section{REFERENCIAS BIBLIOGRÁFICAS}

Baumel, J. Handbook of avian anatomy: Nomina Anatomica avium. 2nd Ed. Publications of the Nuttall Ornithological Club, Harvard University, 1993.

Bezuidenhout, A. The topography of the thoraco abdominal viscera in the ostrich (Struthio camelus). Onderstepoort J. Vet., 53(2):111-7, 1986.

Cooper, R. G. \& , Mahroze, K. M. Anatomy and physiology of the gastro-intestinal tract and growth curves of the ostrich (Struthio camelus). Anim. Sci. J., 75(6):491-8, 2004.

Degen, A.; Duke, G. \& Reynhout, J. Gastroduodenal motility and glandular stomach function in young ostriches. Auk, 111(3):750-5, 1994.

Gamble, K. \& Honnas, C. Surgical correction of impaction of the proventriculus in ostriches. Comp. Cont. Educ. Pract., 15(2):235-45, 1993.

Honnas, C.; Bluemclendon, A.; Zamos, D.; Parson, E. \& Jensen, J. Proventriculotomy in Ostriches-18 Cases (1990-1992). J. Am. Vet. Med. Assoc., 202(12):1989-92, 1993.
Honnas, C.; Jensen, J.; Cornick, J.; Hicks, K. \& Kuesis, B. Proventriculotomy to relieve foreign body impaction in ostriches. J. Am. Vet. Med. Assoc., 199(4):461-5, 1991.

Huchzermeyer, F.; Henton, M. \& Keffen, R. High mortality associated with megabacteriosis of proventriculus and gizzard in ostrich chicks. Vet. Rec., 133(6):143-4, 1993.

McLelland, J. A colour atlas of avian anatomy. London, Wolfe Publishing Ltd., 1990.

Perelman, B. \& Kuttin, E. Zygomycosis in ostriches. Avian Pathol., 21(4):675-80, 1992.

Sanford, S. \& Rehmtulla, A. Impaction in a rhea. Can. Vet. J., 34(3):184-5, 1993.

Sato, Y.; Yasuda, J.; Sinsungwe, H.; Chimana, H. \& Sato, G. An occurrence of stomach impaction in ostriches (Struthio camelus) on a farm in zambia associated with high mortality. J. Vet. Med. Sci., 56(4):783-4, 1994.

Shakespeare, A. Recumbency in ostriches. Comp. Cont. Educ. Pract., 17(11):1440-7, 1995.

Shwaluk, T. \& Finley, D. Proventricular-ventricular impaction in an ostrich chick. Can. Vet. J., 36(2):108-9, 1995.

Streicher, E.; Naude, R.\& Oelofsen, W. The isolation and characterization of pepsinogens from the proventriculus of the ostrich Struthio camelus. Comp. Biochem. Physiol. B., 82(1):67-72, 1985.

Terzich, M. \& Vanhooser, S. Postmortem findings of ostriches submitted to the Oklahoma Animal disease diagnostic laboratory. Avian Dis., 37(4):1136-41, 1993.

Yasuda, M. The anatomical atlas of gallus. Tokyo, Ed. University of Tokyo Press, 2003.

Dirección para correspondencia:

Richard Möller

Universidad de la República

Facultad de Veterinaria.

Área de Anatomía

Lasplaces 1620

CP 11600.

URUGUAY

Email: anatomia.uy@gmail.com

Received: 16-03-2009

Accepted: 23-08-2009 